\section{OBESITY IN CHILDREN IN THE REGIONS OF RUSSIA}

VL Gritsinskaya, VP Novikova*. Saint-Petersburg State Pediatric Medical University

\subsection{6/archdischild-2021-europaediatrics.205}

Introduction The upward steady trend in the prevalence of obesity in the pediatric population during the last decades is a significant medical and social problem.

Objectives Purpose of our research was to study the prevalence of obesity among schoolchildren living in various regions of Russia.

Material and Methods Totally 5701 schoolchildren (2668 boys and 3033 girls) had been enrolled in the cross-sectional study with the use of random sampling techniques at the All-Russian Children's Center 'Orlyonok'. All investigated children were subdivided into two subgroup: I - elementary school children aged 7 to 11 years; II - middle school children aged 12 to 16 years. We measured length and weight of the body and calculated body mass index (BMI). We diagnosed obesity if BMI value was above 95 percentile in accordance with the standards centile scale 'WHO Growth Reference 2007'. Data was analyzed using the statistical package 'STATISTICAv.7.0 (C) STATSOFT, USA'. The results are presented as $\mathrm{P}[\mathrm{CI}] \%$, where $\mathrm{P}$ is the percentage, $\mathrm{CI}$ is the $95 \%$ confidence interval for share. Analysis of statistical significance of differences performed using Pearson $\chi^{2}$ test (with Yates correction).

Results Obesity was diagnosed in 5.6 [5.3-5.9]\%. of schoolchildren. We have identified the following relationships between age, gender, place of residence and obesity. There were more than $16.9[16.2-17.6] \%$ of boys with obesity than $5.2[4.8-5.6] \%$ of girls $(p<0.001)$. There were more girls with obesity in group I $(7.8[6.6-9.0] \%)$ than in group II $(4.7$ $[4.4-5.1] \% ; \mathrm{p}=0.0056)$; the boys have no differences between the groups. More obese children were from Ural (15.4\%), Southern (12.5\%) and North Caucasian (12.1\%) federal districts; lower in Far East (6.2\%), Volga (7.1\%) federal districts.

Conclusion It is important to continue analysis of the factors leading to deviations in the nutritional status of children.

\section{QUALITY OF LIFE IN OBESE CHILDREN}

${ }^{1}$ EB Milner, ${ }^{1}$ VA Guryeva, ${ }^{2}$ IA Burnysheva, ${ }^{3}$ VP Novikova*. 'AVA-PETER Limited Liability Company, Russia, Saint Petersburg; ${ }^{2}$ Regional Children's Clinical Hospital, Russia, Saint Petersburg; ${ }^{3}$ Saint Petersburg State Pediatric Medical University, Russia, Saint Petersburg

\subsection{6/archdischild-2021-europaediatrics.206}

Objectives To examine the health-related quality of life of obese children Materials and methods: We conducted a survey among 36 children between the ages of 13 and 17, who had been diagnosed with obesity class 2 and class 3 (according to WHO classification), during their routine examination in Regional Children's Clinical Hospital in Saint Petersburg. Results were compared with 22 schoolchildren of 9th grade of secondary school with normal body mass index in first health group in accordance with their medical records. We examined life quality with the Short Form-36. Patients filled out a questionnaire on their own when they were included in the study.

Statistical analysis of the results was carried out using Student's t-test.
Results The average values of the quality of life indicators on the general health perceptions scale $(\mathrm{GH})$, which reflect the patients' assessment of their current state of health and disease resistance, were lower in obese children than in the control group $(54,8 \pm 3,7$ vs $88 \pm 1,2, \mathrm{p}<0,05)$; vitality scores (VT), that reflect a feeling of being full of strength or, on the contrary, being exhausted, in obese children were lower than in the control group $(62,8 \pm 2,8$ vs $90 \pm 1,4, \quad p<0,05)$ mental health scores $(\mathrm{MH})$, which reflect moods and presence of negative emotions, again were lower among obese children $(67,8$ $\pm 3,8$ vs $88 \pm 1,6, p<0,05)$. The life quality indicators on the remaining scales in obese children although were lower than in healthy children, however, no significant differences were obtained.

So, physical functioning scores (PF), which reflect children's abilities to self-service and fulfill different physical activities were $81,7 \pm 3,4$ in obese children vs $92,0 \pm 1,8$ in control group, $p>0,05$; Results of physical role functioning scale (RP), were $80,6 \pm 7,7$ vs $86 \pm 2,1, p>0,05$; Scores of social functioning scale (SF), which reflect the degree of how physical and emotional states limit levels of social adaptation and satisfaction were $84,8 \pm 4,6$ vs $90 \pm 2,3, p>0,05$; Finally, emotional role functioning scores (RE) were $85,2 \pm 6,7$ vs $94 \pm 3,1$, $\mathrm{p}>0,05$.

Conclusion Life quality scores of obese children and adolescents are lower in comparison with control group. That is why physicians must target special interventions that could enhance health outcomes.

\section{LEVEL OF ERYTHROPOIETIN, SVCAM-1 AND VEGF IN BLOOD OF OBESE ADOLESCENTS}

${ }^{1,2} \mathrm{VP}$ Novikova*, ${ }^{2} \mathrm{VL}$ Gritsinskaya, ${ }^{2} \mathrm{Yu} V$ Petrenko, ${ }^{2} \mathrm{MM}$ Gurova, ${ }^{2} \mathrm{OP}$ Gurina, ${ }^{2} \mathrm{ON}$ Varlamove? ${ }^{2} \mathrm{AE}$ Blinov, ${ }^{2} \mathrm{EL}$ Strukov, ${ }^{1} \mathrm{NN}$ Smirnova, ${ }^{1} \mathrm{NB}$ Kuprienko, ${ }^{3} \mathrm{~EB}$ Milner. ${ }^{1} \mathrm{~S}$. Petersburg First Medical University, Russia, St. Petersburg; ${ }^{2}$ St. Petersburg State Pediatric Medical University, Russia, St. Petersburg: ${ }^{3}$ AVA-PETER LLC, Russia, St.Petersburg

\subsection{6/archdischild-2021-europaediatrics.207}

Introduction Erythropoietin is considered as a protective tissue cytokine that increases angiogenesis. Obesity is associated with the development endothelial dysfunction, playing a key role in the pathogenesis of metabolic syndrome complications.

Objectives To determine the level of erythropoietin and presence of markers of endothelial cell dysfunction sVCAM-1 and VEGF-A in the blood of adolescents with obesity.

Methods We examined 22 teenagers with obesity (body mass index - BMI - from 30.1 to 42.87) and 22 teenagers with normal BMI. The age of patients ranged from 13 to 18 years (average of $14.25 \pm 1.2$ ). We analyzed serum concentrations of vascular cell adhesion molecule 1 (sVCAM-1) and vascular endothelial growth factor A VEGF-A - markers that indicate the presence of endothelial dysfunction. Data was analyzed with the use of statistical package Statistica 10.0 for Windows10. The significance of the differences was determined at $\mathrm{P}$ value $<0.05$

Results Concentration of sVCAM-1 (1395.23 $\pm 264.73 \mathrm{ng} / \mathrm{ml}$ vs $847.44 \pm 190.23 \mathrm{ng} / \mathrm{ml} ; \mathrm{p}<0.0001)$ and VEGF-A $(75.89$ $\pm 54.79 \mathrm{pg} / \mathrm{ml}$ vs $6.22 \pm 5.74 \mathrm{pg} / \mathrm{ml} ; \mathrm{p}<$

0.0001) was higher in patients with obesity compare to the adolescents with the normal BMI. The correlation between the level of sVCAM-1 and BMI $(r=0,45 ; \mathrm{p}<0,05)$. 